UDC: $378.147: 378.046 .4(477)$

Oleksandr L. Shums'kyi

$\mathrm{PhD}$ of Pedagogical Sciences, Candidate for a Doctor's Degree at the Department of

Pedagogy and Psychology of Educational Activities

Zaporizhzhia National University, Zaporizhzhia, Ukraine

ORCID ID 0000-0002-9498-7509

oll123@meta.ua

\title{
USE OF IT FOR FUTURE FOREIGN LANGUAGE TEACHERS' LINGUISTIC SELF-EDUCATION
}

\begin{abstract}
The article substantiates that large-scale implementation of information technologies will facilitate methodological support of future foreign language teachers' linguistic self-education.

The main functions and advantages of the author's multimedia training package "English for SelfEducation", designed to support future foreign language teachers' linguistic self-educational activities, are characterized. It is defined that the package is an open-ended multipurpose programmatic learning system, containing didactic, methodological, informational and reference materials. The package is based on general pedagogical, ergonomic and specific principles of informatization of education.

It has a dual structure, which includes two levels. The first level contains 1) lexical-informational component that provides working with lexical and theoretical material, 2) training element, which enables practicing knowledge and skills, as well as mastering methods and means of autonomous managing, regulating and correcting the process of linguistic self-education, 3) control aspect, which allows realizing independent monitoring and evaluating the degree and quality of acquired knowledge and skills. The second level considerably extends didactic possibilities and educational resources of the package. It covers a wide range of extra learning materials of theoretical and practical nature that are available both in the package itself and beyond its limits through providing the access to the "virtual reality" within external resources of global network. All the above not only makes for activating students' cognitive activity but also significantly enriches their language and sociocultural practice.

The package enables comprehensive independent study of a foreign language, exercising selfdiagnostics in order to detect gaps in the student's foreign-language competence, performing intensive linguistic self-educational activities, constant monitoring the level of autonomously mastered foreign-language material, carrying out search for information, etc.

Thus, the package provides optimal conditions for future foreign language teachers' linguistic selfeducational activities. Students have an opportunity to actualize the adaptive algorithm of building the individual trajectory of linguistic self-education in accordance with their psychological features and personal educational needs.

It is shown that working with the package results in students' receiving an external and internal educational products, namely improving foreign-language knowledge and skills, along with gaining personal experience of linguistic self-educational activities.

It is grounded by the example of the proposed package that comprehensive use of IT significantly optimizes the process of linguistic self-education.
\end{abstract}

Keywords: linguistic self-education; multimedia training package; foreign language teachers; informatization of self-education.

\section{INTRODUCTION}

Statement of the problem. The $21^{\text {st }}$ century is characterized by the humankind's transition from industrial to postindustrial model of civilizational evolution. This entails the formation of new, informational society, in which information is the main product of demand and supply. In this context, among other things, future foreign language teachers cannot completely satisfy their ever-growing linguistic self-educational needs by means of solely traditional paper-based instructional materials. A large-scale implementation of educational 
information technologies is one of the most effective ways to achieve this aim. By means of IT it is possible to cardinally change the nature of linguistic self-educational process, in particular to expand opportunities, provide universal access to large volumes of authentic language information, modify existing and create new methods of linguistic self-educational activities, form or transform certain personal and professional qualities of future foreign language teachers in the course of their academic preparation for life-long linguistic selfeducation.

Analysis of recent research and publications. The issues of modernization of education by means of all-round informatization are widely discussed by the representatives of both international academic community (B. Fernández-Manjón [1], H.-W. Zuo [2], D. Lushchykova [3]) and Ukrainian researchers (V. Kremen' [4], V. Madzihon [5], O. Ovcharuk [6], V. Vember [7]). In many parts of the world, including Ukraine, the problem of adapting young generation to living in information society is also resolved at the legislative level [8], [9], [10].

Along with ever-advancing informational support of education at large, the aspects of informatization of linguistic self-education, as a new field of pedagogy, are being extensively studied as well (C. Chia [11], O. Shcholok [12], S. Yao [13]).

The purpose of the article is to describe operational characteristics and analyze the didactic possibilities of applying modern means of information technologies in the course of future foreign language teachers' linguistic self-education by the example of the author's multimedia training package "English for Self-Education".

\section{METHODS}

The research is based on such methods as analysis, synthesis, comparison, systematization and generalization of theoretical and methodological aspects of organizing future foreign language teachers' linguistic self-education by means of information technologies.

\section{FINDINGS}

At present widespread introduction of information technologies makes it possible to more effectively address the problem of methodological support of future foreign language teachers' linguistic self-education. Means of information technologies can be defined as hardware and software which operate on microprocessor-based systems and enable collecting, generating, saving, processing and transmitting information [14, p. 9]. IT, including automated instructional applications, are used as an instrument of organizing and facilitating linguistic self-educational activities. In view of this, we developed a multimedia training package "English for Self-Education" (hereinafter - Package) in order to arrange the process of future foreign language teachers' linguistic self-education. In the design phase we tried to maximally compensate for the deficiencies of already existing educational software applications.

The Package can be defined as virtual learning environment, in which the student can perform linguistic self-educational activities. The synthesis of basic theoretical points of pedagogy, didactics, electronic linguodidactics, psychology, physiology, linguistics, autodidactics, linguistic autodidactics, communication theory makes up the scientific and methodological frame of the Package.

The Package is developed in accordance with a number of general pedagogical, ergonomic and specific principles of informatization of training.

For example, the principle of "matrioshka" nesting doll enables folding and unfolding virtual realities one inside another by means of a number of integrated appendices in the way 
of "a textbook in a textbook". With the help of appropriate instruments students can define the general level of language proficiency, detect the degree of formedness of all speech skills (reading, writing, listening, speaking), carry out self-diagnostics of their own psychophysiological characteristics in order to find their individual style of mastering a foreign language. Methodology of self-diagnostics, integrated in the respective block of the Package, is of great importance for teaching students learning autonomy. This toolkit helps future foreign language teachers to understand the mechanisms of training, thinking, memorizing instructional material and complete linguistic tasks. Besides, before starting the work with the Package, students are supposed to practice basic strategies of independent foreign language study. The strategies are arranged in the theoretical and practical guide. If the student needs more profound knowledge in grammar or phonetics, he or she can watch a series of video-lectures delivered by English language teachers - native speakers. Depending on individual or professional needs students can also consult a reference-book on commercial correspondence. In accordance with the nesting doll principle, all the appendices are presented in a folded format and they can be easily unfolded by means of the appropriate buttons on the page with the main menu of the Package.

The principle of system quantization implies compressing learning information by means of generalizing the content. In accordance with this principle we singled out and schematically grouped the critical minimum of the most common English grammar rules and phonetic peculiarities, which is supposed to serve as a compulsory starting point for further independent acquisition of linguistic knowledge.

All the above-listed theoretical and practical appendices help students to master the techniques of self-management and self-regulation, as well as basic strategies of productive linguistic self-educational activities. Thereby, students can autonomously work with learning material (textbooks, periodicals, reference-books, dictionaries) on the basis of their own instructions and algorithms. Moreover, they acquire the skills of making notes, logical schemes, frames, etc.

The Package has a hypertext structure, which means that all underlined lexical units and virtual buttons are hyperlinks. By clicking on them the user can instantly proceed to any place of the Package. The hyperlink system, along with the functions of hypermedia (presenting instructional information in text-, graphic, audio-, video- and animation formats), according to the principle of branching, allowed us to connect screen pages and various learning modules into the integrated training complex.

Thus, the above-mentioned functions simplify navigation, give the student an opportunity to define the optimal trajectory of linguistic self-educational activities, choose comfortable work pace and the format of presenting learning material in compliance with their individual psychophysiological features in order to ensure more effective perception of information. Furthermore, it is possible to adapt the course content to the needs of a concrete user by means of varying its depth, degree of complexity and applied orientation, which makes it easier for students to select their own self-educational trajectory.

In view of the fact that linguistic self-educational activities are performed by the student solely on their own initiative, on free will and without any external pressure, when designing the Package we paid considerable attention to the issue of activation of students' internal selfstimulating processes. So, if while completing a task a student suddenly loses faith in their own strength or aptitude, they can press the "M" (Motivation) button, which is present on each page. It reduces overpressure and restores emotional balance of the user by means of a certain foreign-language motivational video, an inspiring aphorism by some prominent polyglot, scientist, writer, etc.

According to the principle of computer support, in order for the student to feel psychologically comfortable while working with the Package and prevent the state of anxiety, 
they are advised to study the "User guide" - a detailed step-by-step manual on how to work with the Package. It is possible to get to the user guide from each screen page of the Package and at any time by pressing the appropriate button. Besides, each page contains "Help" button, which serves for clarifying technical difficulties that can arise while working on this particular page.

In concordance with the principle of composition, the Package is open for making any modifications. It is possible for the teacher to add new topics or sections to the content and broad learning materials, whereas students can make up their own electronic vocabulary or create a personal virtual library.

The Package has a dual structure, including two levels. The first level contains 1) lexical-informational component that provides working with lexical and theoretical material, 2) training element, which enables practicing knowledge and skills, as well as mastering methods and means of autonomous managing, regulating and correcting the process of linguistic self-education, 3) control aspect, which allows realizing independent monitoring and evaluating the degree and quality of acquired knowledge and skills. The second level considerably extends didactic possibilities and educational resources of the Package. It covers a wide range of extra learning materials of theoretical and practical nature that are available both in the Package itself and beyond its limits through providing the access to the "virtual reality" within external resources of global network. All the above not only makes for activating students' cognitive activity but also significantly enriches their language and sociocultural practice.

Direct access to the Internet is provided by the following screen buttons: «D» (online dictionary and translator), «W» (English version of Wikipedia) and «S» (Google search), placed on each screen page. Moreover, at the end of each advanced-level task we offer a list of hyperlinks to websites on this particular subject area because the student will probably need more detailed information or more painstaking practicing.

With a view to ensure the perceptual unity of materials and optimize navigation process, the first page of the Package contains its contents. Each item of the contents is a virtual button, by clicking on which the user can instantly move to the needed section of the Package (Fig. 1).

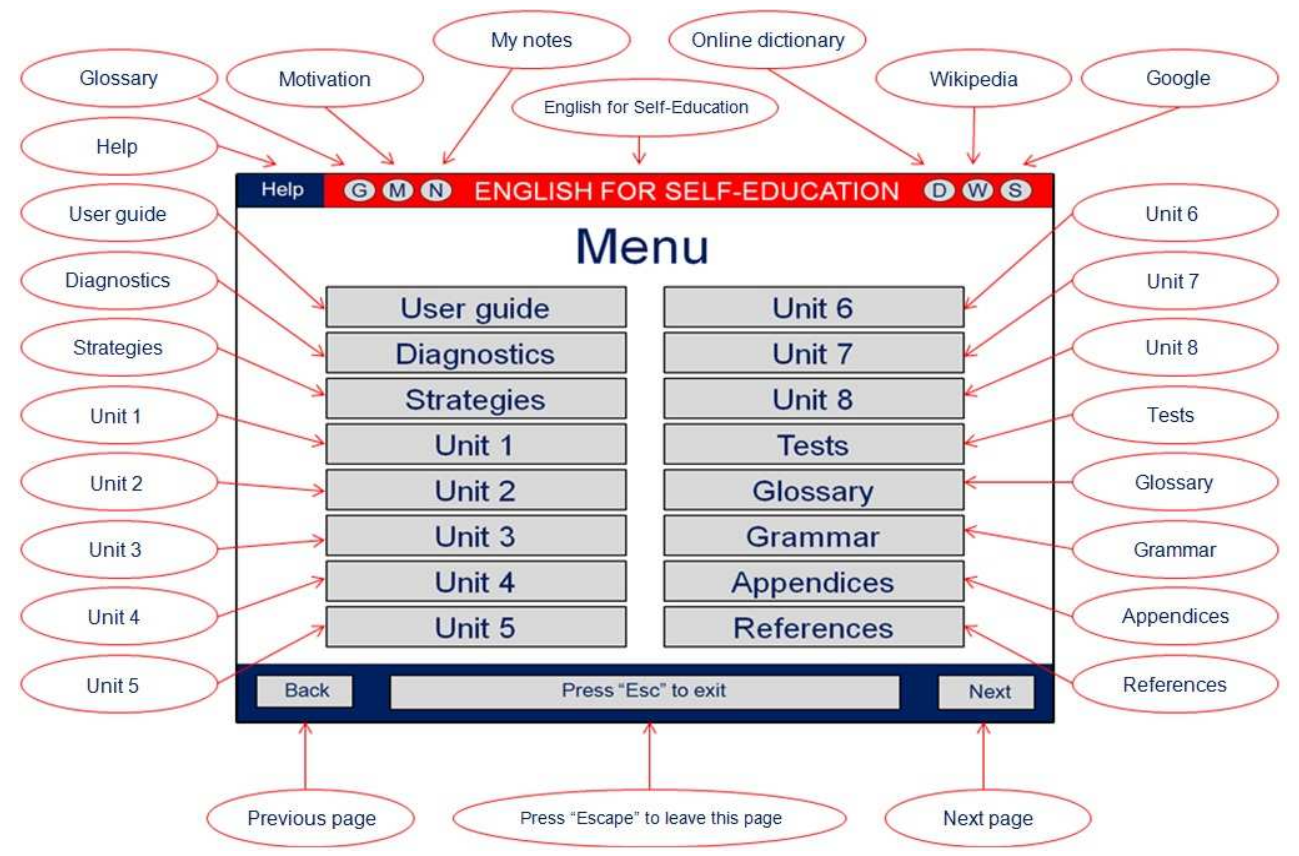

Figure 1. Contents of multimedia training package "English for Self-Education" 
In order to achieve the highest possible effectiveness of self-instruction it is important that learning information is given in various forms. In this case the user has the adaptive choice of one or several means - "catalysts" of perceiving language information with due regard for their dominant memory type, namely: associative, emotional, visual, auditory, etc., as well as for the prevailing type of sensory modality, that is the predominant canal of perception. For this reason the content of each unit of the Package is presented in textual, video-, audio-, animation and graphic formats.

Every unit of the Package is a chronological sequence of blocks, namely: "Vocabulary", "Starting", "Reading", "Writing", "Listening", "Video", "Speaking" and "Test". This allows to begin work with any aspect of language material or type of speech activity. Besides, the student can manage the process of their linguistic self-education, coordinate intermediate results and monitor the dynamics of language proficiency upon completing each unit. Before starting work with the units of the Package, we recommend that the student detect existing problem zones and deficiencies in their own foreign-language knowledge and skills with the help of appropriate self-diagnostic techniques, offered in "Diagnostics" section. After that he / she has an opportunity to uncover the types of speech activity which above all need to be improved. In such a way the student can define a priority block for immediate completion, make up individual algorithm of linguistic self-educational operations, select an acceptable degree of complexity of tasks, choose the needed learning material, arrange it and define optimal volume, plan the sequence of execution, select methods and strategies of its mastering, analyze and evaluate the results of linguistic self-educational activities. Thanks to that the student will be able to prognosticate, coordinate and control the process of their own linguistic self-education, which will notably increase the degree of responsibility for its course and results, as well as stimulate motivation for independent study.

In order for the student to master the mechanisms of autonomous language learning it is relevant to place him / herself in the position of a teacher. With this in mind we included a number of specific linguistic exercises in the Package. These exercises contain not only speech tasks but also automethodological ones, e. g. exercises on systematizing mono- and intercultural linguistic information, detecting and overcoming language deficiencies, autonomous acquisition of new lexical units, automethodological analysis of the latest linguistic self-educational activities and making plans for the near future.

Besides, the Package provides orientation tools for performing effective linguistic selfeducational activities, including specific algorithms, sample actions and respective methodological instructions. Students complete tasks in accordance with stepwise recommendations and proposed algorithms. All the above-mentioned constituents assist in structuring students' knowledge and putting in order mental activity with due regard for their capabilities of learning to learn.

The content of linguistic self-educational tasks varies depending on the type of learning situation and its orientation, namely linguistic, linguomethodological, informationalcognitive, professional, etc. For instance, there are tasks on independent searching and acquiring language knowledge; communicative skills; mastering the modes of language learning; selecting appropriate logical and semantic anchors, marker words, signal lexical units in a text; making the denotative reference scheme of a text or speech situation; building semantic, logical, associative diagrams for memorizing words, etc.

In order to complete linguistic self-educational tasks students are supposed to apply the method of situation analysis. This method enables developing critical thinking skills and helps to independently gain the skills of solving certain situational problems, making own algorithms of managerial actions, taking rational decisions, etc.

In compliance with the suggested sequence of blocks within the Package the students' step-by-step work with each of them maps out their individual route of linguistic self- 
educational activities. This route includes harmonious study of all aspects of the foreign language as an integral system, namely: phonetics, vocabulary, grammar, reading, writing, speaking and listening.

Every screen page of the Package contains a number of virtual buttons (Fig. 2).

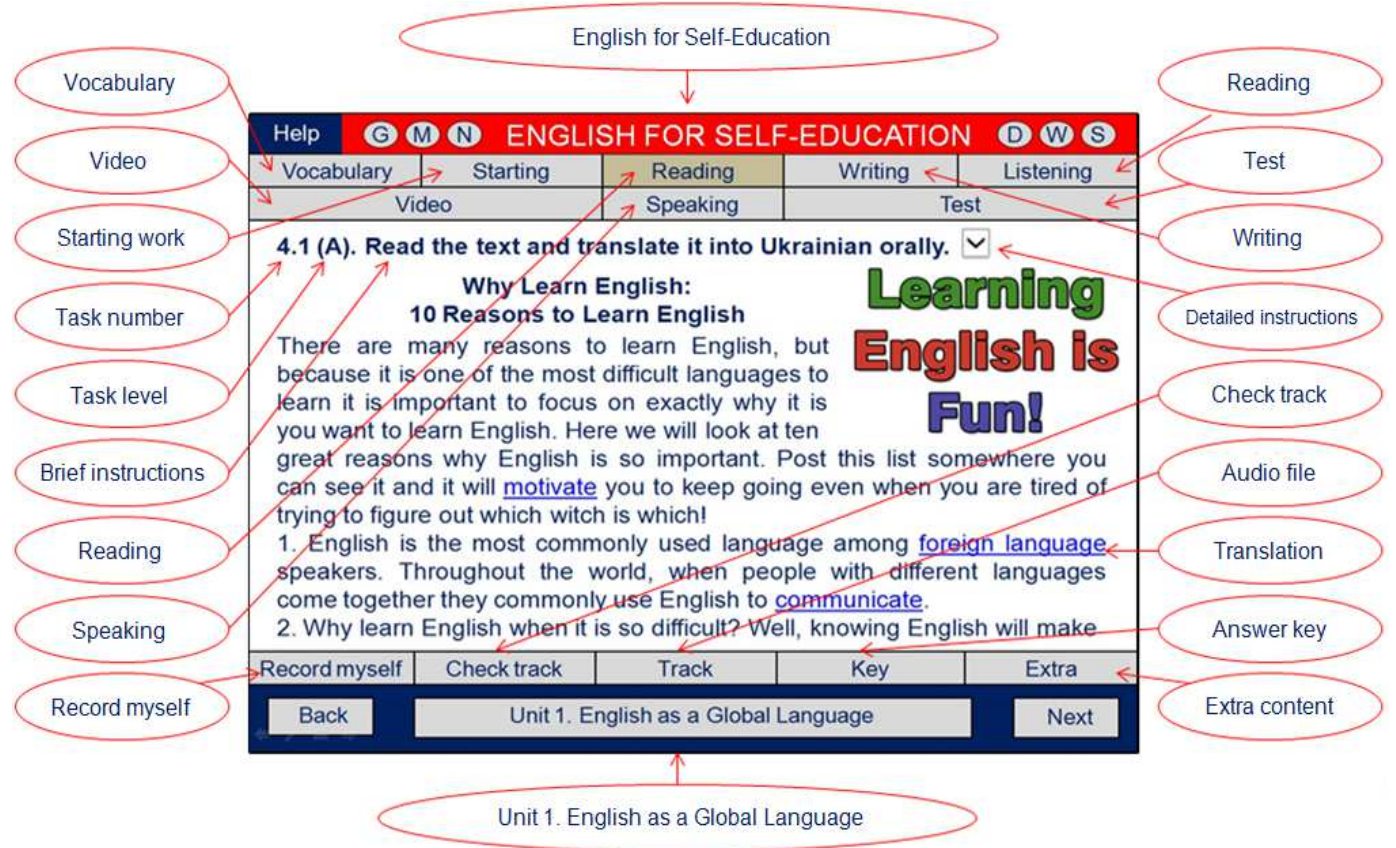

\section{Figure 2. Fragment of the first unit of multimedia training package "English for Self- Education”}

The set of functional virtual buttons of the bottom row varies depending on the orientation of a particular block or certain task. Thereby, most of the tasks in different blocks are universal as they can be completed both orally and in writing. For example, "Track" button is available not only in "Listening" block, but also in "Reading" block. Such option, when required, enables the simultaneous activation of two information perception canals audible and visual ones. "Transcript" button, which is present in "Listening" block, serves for realizing this function too. What is more, students can record and check their answers. All the above-mentioned options boost psychophysiological mechanisms, sensory systems of the brain, the mechanism of synchronizing the work of visual and audible sensors and verbalmotor analyzer, which significantly enhances the quality of information acquired.

The Package has the search function, based on hypertext technology, which ensures the highest possible comfort while working with textual content and lexical units. Owing to this we have been able to create the didactic material of qualitatively new level, which allows students not only to get individual comments to each task, but also provides them with immediate access to the whole bulk of reference information of the Package, which is necessary for performing multidimensional practical tasks. So, by clicking on an underlined word - a hyperlink, - if it is necessary, the student can check the translation of a lexical unit, which will appear in a supplemental window.

Furthermore, with the help of "G" (Glossary) button the user can move to the general lexicon, which is added to the Package. The glossary has a hypertext basis. It consists of nearly two thousand lexical units and word-combinations. Each of them is supported with a transcription and abbreviated reference to the part of speech. In view of the fact that working with the Package stipulates full autonomy without any external assistance, for the purpose of self-check, correcting or improving pronunciation the student can make use of the 
vocalization function, namely, listen to the correct phonetic image of each word in the glossary by clicking on it with the left key of the mouse.

Contemporary psychologists [15] emphasize that the existing educational technologies, traditionally aimed at developing verbal-logical thinking of students, do not fully meet the needs of information age generation. The typical $21^{\text {st }}$ century student's cognitive sphere is characterized by so-called "clip thinking", which is a natural mechanism of adaptation to the present-day oversaturated information space, as well as by representative and emotional patterns of mental activity that result from the strong influence of mass media.

In the light of this, we believe that simultaneous forming and developing students' theoretical and representative thinking is an important factor of effective independent foreign language learning. This can be actualized through teaching them to actively apply visual strategies of working with foreign-language information by means of "transformation and subjective-semantic interpretation of the image" [16, p. 285], which requires mastering a wide range of such intellectual operations as analysis, synthesis, generalization, comparison, matching, abstracting, classifying, categorizing, systematization, structuring, coding, transformation, modeling, interpreting, etc. Such mode of thinking has a complex integral structure and reflects relations of objective reality with the help of various forms of visual encoding at a metaverbal level. In our opinion, visual support of verbal information is an efficient intellectual instrument, which can help to speed up processing foreign-language instructional information and memorizing lexical units of any form, length and complexity, as well as their retention; to boost motivation and positive attitude towards linguistic selfeducation.

On assumption that self-organization and self-control are the key links of the system of self-management of linguistic self-educational activities, the higher is the level of formedness of these skills of students, the more productivity they display in these activities. Therefore, every unit of the Package contains the control block ("Test"), which makes it possible to detect the percentage of learning information acquired and objectively evaluate knowledge and skills within the scope of the material of a certain unit. Eventually, the student can carry out the final self-check upon completing the whole instructional content of the Package by proceeding to "Final test" block.

Due to such continuous monitoring students are encouraged to consciously, appropriately and systematically keep track of their own progress. Consequently, they will gradually move on to the internal self-control, as the acme of reflective skills, and therefore there will be no need for any external control.

\section{CONCLUSIONS AND PROSPECTS FOR FURTHER RESEARCH}

Rapid development of information technologies determined the emergence of digital format of educational and self-instructional content, which is characterized by a wide range of methodological and didactic innovations.

The author's multimedia training package "English for Self-Education" has been developed in order to activate and support future foreign language teachers' linguistic selfeducational activities. The package is based on general pedagogical, ergonomic and specific principles of informatization of education.

The package, as a virtual learning environment, has a multifunctional interface, which provides a wide range of opportunities for performing linguistic self-educational activities in accordance with the interests and needs of each student. It also makes these activities more purposeful, systematic and regular. In the course of stepwise completion of all tasks students will be able to build their individual trajectory of linguistic self-education without any external assistance. 
Working with the package allows optimizing the process of linguistic self-education, which will help future foreign language teachers to independently improve foreign language proficiency.

Within the further research we are planning to study the linguodidactic potential of mlearning in organizing future foreign language teachers' linguistic self-education, in particular methodological and didactic aspects of developing cross-platform applications for mobile devices in order to ensure comprehensive autonomous foreign language learning.

\section{REFERENCES (TRANSLATED AND TRANSLITERATED)}

[1] B. Fernández-Manjón, J.-M. Sánchez-Pérez, J.-A. Gómez-Pulido, Eds. Computers and education: Elearning, from theory to practice. New York: Springer, 2007. (in English).

[2] H.-W. Zuo, G.-H. Sun. "Research on network informatization tactics of continuing education in Yunnan University under the background of "Internet +". 2017 International Conference on Energy, Environment and Sustainable Development (EESD 2017). pp. 260-265. (in English).

[3] D. V. Lushchykova. "Value of the personality's self-development in information society". Problemy suchasnoii psykholohii: zb. nauk. pr. K-PNU im. Ivana Ohiienka, Instytutu psykholohii im. H. S. Kostiuka APN Ukrainy. Iss. 10. pp. 418-427. 2010. (in Ukrainian).

[4] V. H. Kremen'. "Information and communication technologies in education and forming information society". Informatyka ta Informatsiini Tekhnolohii v Navchal'nykh Zakladakh. No. 6. pp. 5-9. 2006. (in Ukrainian).

[5] V. M. Madzihon. "Informatization of education in Ukraine: state, problems and perspectives. Kompiuter u shkoli ta simii. No 8. pp. 3-8. 2011. (in Ukrainian).

[6] O. Ovcharuk. "Tendencies of informatization of education and using information and communication technologies for improving the quality of education". Shliakh osvity. No 2. pp. 19-22. 2007.

[7] V. Vember. "Informatization of education and problems of introducing educational program tools in learning process". Informatsiini Tekhnolohii $i$ Zasoby Navchannia. Iss. 3. [Online]. Available: https://core.ac.uk/download/pdf/19666764.pdf. Accessed on: May 6, 2019. (in Ukrainian).

[8] Pro zatverdzhennia Derzhavnoi prohramy "Informatsiini ta komunikatsiini tekhnolohii v osviti i nautsi" na 2006-2010 rr. Postanova Kab. Min. Ukrainy vid 7.12.2005 r. No 1153. [Online]. Available: https://www.kmu.gov.ua/ua/npas/25596940. Accessed on: December 2, 2018. (in English).

[9] Digital Education Action Plan. [Online]. Available: https://ec.europa.eu/education/education-in-theeu/digital-education-action-plan_en. Accessed on: December 5, 2018. (in English).

[10] Europe 2020 strategy. [Online]. Available: https://ec.europa.eu/info/business-economy-euro/economicand-fiscal-policy-coordination/eu-economic-governance-monitoring-prevention-correction/europeansemester/framework/europe-2020-strategy_en. Accessed on: December 5, 2018. (in English).

[11] C. Chia. Autonomy in language learning: The use of IT and Internet resources. New York: McGraw-Hill Education. 2007. (in English).

[12] O. B. Shcholok. "Phenomenon of self-education in information society". Kompiuterno-oriientovani systemy navchannia. Iss. 3 (10). Kyiv: NPU im. M. P. Drahomanova. pp. 318-323. 2005. (in Ukrainian).

[13] S. Yao. "Research on Web-based autonomous English learning of Engineering students". iJET. Vol. 11, Iss. 6. pp. 4-9. 2016. (in English).

[14] I. V. Robert, S. V. Paniukova, A. A. Kuznetsov, Eds. Information and communication technologies in education. Moscow: Drofa, 2008. (In Russian).

[15] S. Buck-Morss. "Visual studies and global imagination: Papers of surrealism". Iss. 2. 2004. [Online]. Available:http://susanbuckmorss.info/text/visual-studies-and-global-imagination/. Accessed on: December 6, 2018. (in English).

[16] M. Denis, J. Engelkamp, J. Richardson, Eds. Cognitive and neuropsychological approaches to mental imagery. New York: Springer. 2011. (in English). 


\title{
ВИКОРИСТАННЯ ІНФОРМАЦІЙНИХ ТЕХНОЛОГІЙ ДЛЯ ЛІНГВОСАМООСВІТИ МАЙБУТНІХ УЧИТЕЛІВ ІНОЗЕМНИХ МОВ
}

\section{Шумський Олександр Леонідович}

кандидат педагогічних наук, докторант кафедри педагогіки та психології освітньої діяльності Запорізький національний університет, м. Запоріжжя, Україна

ORCID ID 0000-0002-9498-7509

oll123@meta.ua

\begin{abstract}
Анотація. У роботі обгрунтовано, що одним із шляхів вирішення проблеми навчальнометодичного забезпечення лінгвосамоосвіти майбутніх учителів іноземних мов має стати широке впровадження інформаційних технологій, які надають можливість сформувати новий, автономний, тип студента.

Розглянуто та схарактеризовано основні функції і переваги мультимедійного навчального комплексу «English for Self-Education», розробленого автором статті з метою активізації та підтримання процесу лінгвосамоосвіти майбутніх учителів іноземних мов.

Визначено, що означений комплекс являє собою відкриту навчальну програмну систему комплексного призначення, яка містить дидактичні, методичні, інформаційно-довідкові матеріали, що що допомагають самостійно вивчати всі аспекти іноземної мови як цілісної системи, і надає можливість за допомогою відповідних методик проводити самодіагностику 3 метою виявлення прогалин і дефіцитів у власній іншомовній підготовці, здійснювати інтенсивну пізнавальну і тренувальну лінгвосамоосвітню діяльність, контролювати рівень самостійно засвоєного іншомовного матеріалу, а також реалізовувати інформаційнопошукову діяльність, у результаті чого забезпечується неперервність i повнота дидактичного циклу процесу формування всіх ланок готовності до неперервної лінгвосамоосвіти.

Виявлено, що результатом роботи 3 комплексом $є$ одержання студентом зовнішнього освітнього продукту у вигляді приросту іншомовних знань, умінь та навичок; внутрішнього освітнього продукту у формі суб'єктного досвіду лінгвосамоосвітньої діяльності; сформована готовність до лінгвосамоосвіти як інтегративна якість особистості, що демонструє ступінь оволодіння означеним видом діяльності та рівень розвитку самостійності студента.

На прикладі пропонованого мультимедійного навчального комплексу «English for SelfEducation» доведено, що використання засобів інформаційних технологій значною мірою сприяє оптимізації процесу лінгвосамоосвіти і формуванню студента як суб'єкта власної лінгвосамоосвітньої діяльності.
\end{abstract}

Ключові слова: лінгвосамоосвіта; мультимедійний навчальний комплекс; майбутні вчителі іноземних мов; інформатизація самоосвіти.

\section{ИСПОЛЬЗОВАНИЕ ИНФОРМАЦИОННЫХ ТЕХНОЛОГИЙ ДЛЯ ЛИНГВОСАМООБРАЗОВАНИЯ БУДУЩИХ УЧИТЕЛЕЙ ИНОСТРАННЫХ язЫкОВ}

\author{
Шумский Александр Леонидович \\ кандидат педагогических наук, \\ докторант кафедры педагогики и психологии образовательной деятельности \\ Запорожский национальный университет, г. Запорожье, Украина \\ ORCID ID 0000-0002-9498-7509 \\ oll123@meta.ua
}

\begin{abstract}
Аннотация. В работе обосновано, что одним из путей решения проблемы учебнометодического обеспечения лингвосамообразования будущих учителей иностранных языков должно стать широкое внедрение информационных технологий, предоставляющих возможность сформировать новый, автономный, тип студента.

Рассмотрены и охарактеризованы основные функции и преимущества мультимедийного учебного комплекса «English for Self-Education», разработанного автором статьи с целью активизации и поддержания процесса лингвосамообразования будущих учителей иностранных языков.
\end{abstract}


Определено, что указанный комплекс представляет собой открытую учебную программную систему комплексного назначения, содержит дидактические, методические, информационно-справочные материалы, позволяющие осуществлять гармоничное самообучение всем аспектам иностранного языка как целостной системы, и дает возможность с помощью соответствующих методик проводить самодиагностику с целью выявления пробелов и дефицитов в собственной иноязычной подготовке, осуществлять интенсивную познавательную и тренировочную лингвосамообразовательную деятельность, контролировать уровень самостоятельно усвоенного иноязычного материала, а также реализовывать информационно-поисковую деятельность, в результате чего обеспечивается непрерывность и полнота дидактического цикла процесса формирования всех звеньев готовности к непрерывному лингвосамообразованию и постепенный переход от учебной к профессиональной лингвосамообразовательной деятельности.

Выявлено, что результатом работы с комплексом является получение студентом внешнего образовательного продукта в виде прироста иноязычных знаний, умений и навыков; внутреннего образовательного продукта в форме субъектного опыта лингвосамообразовательной деятельности; сформированная готовность к лингвосамообразованию как интегративное качество личности, демонстрирующее степень овладения указанным видом деятельности и уровень развития самостоятельности студента. На примере предлагаемого мультимедийного учебного комплекса «English for SelfEducation» доказано, что использование средств информационных технологий в значительной мере способствует оптимизации процесса лингвосамообразования и формированию студента как субъекта собственной лингвосамообразовательной деятельности.

Ключевые слова: лингвосамообразование; мультимедийный учебный комплекс; будущие учителя иностранных языков; информатизация самообразования.

\section{(cc) BY-NC-SA}

This work is licensed under Creative Commons Attribution-NonCommercial-ShareAlike 4.0 International License. 